\title{
IN-SERVICE TRAINING FOR TEACHERS OF ENGLISH \\ IN THE LANGUAGE LABORATORY
}

by LILIANA BALTRA. M.

Ministry of Education

Center for In-Service Training

and Educational Research, CHILE.

\section{INTRODUCTION:}

The acquisition of thirty language laboratories by the Ministry of Education was considered a great conquest by Chilean teachers of English as a foreign language who were beginning to feel by then - 1969 - a little bit behind in the advancements of technology.

By the time the labs were shipped, disembarked, had entered in and out of customs and finally were stored at the electronics equipment department of the Ministry of Education, a new government was in office with quite a different educational policy.(1)

Thus, the thirty labs purchased through an Alliance for Progress contract remained stored for three years. No provision was made against weather changes, humidity and vandalism. When the present Language Laboratory Committee found them, in April 1974, they were in a deplorable condition. Some members of this Committee had as their immediate task the repairing, distribution and installation of those labs among the twelve regions of the country.

However, prior to that task, the Committee felt that a detailed Language Laboratory Project for Chile had to be set up. The objectives for the use of the equipment, consequently had a preponderant role.

(1) Chile had a socialist government from 1970 to 1973.

\section{THE LANGUAGE LABORATORY PROJECT.}

The starting points for the Committee in charge of this Project were:

a) There were thirty language laboratories -INSTRUCTOMATIC- with 30 positions; $20 \mathrm{AA}$ and $10 \mathrm{AAC}$ to be distributed in the country;

b) There was a limited budget for repairs and installation and no possibilities of getting more equipment;

c) The effectiveness of the language laboratory with secondary school students in more developed nations was being questioned.

After some deliberation it was decided that the language labs would be used for in-service training of teachers of English and French and that the labs would be installed according to the distribution of teachers in the country. 
Considering the fact that teachers are continually complaining of the lack of opportunities to practice the language they had once learned, and that they are continually involved in their schools, the order or priorities for the use of the labs was established according to the following objectives:

1. To provide in-service training for foreign language teachers in Secondary Schools;

2. To provide practice in the foreign languages for future teachers who are at present studying at universities;

3. To give highly-motivated students of secondary schools an opportunity to practice the language.

Working with the idea that the most important factor in the instructional process is the teacher, the Language Laboratory Project has structured its activities to provide a new type of training for any teacher of English or French willing to improve his mastery of the language through systematic practice in the language laboratory.

By the time this project was launched, the Ministry of Education had begun its decentralization policy. Teams of teachers were being trained from all the regions in order to provide in-service training courses to all teachers involved in the national system. Consequently, simultaneous with the installation of the labs, the training of laboratory monitors began with this Center having the responsibility of the organization and teaching of the seminars.

Teachers with a good command of the language were selected from all the cities where the labs were being installed. A select group of specialists from the University of Chile (Santiago, S. Oriente), the British Institute, the British Council and the Northamerican Institute participated actively in these Seminars and contributed greatly towards a sound systematization of the whole project.

\section{THE TRAINING SEMINARS.}

Considering the fact that the group of trainees consisted mainly of regular teachers whose only job was teaching in the classroom, the use of the lab presented some intricacies. Therefore, it was felt that the teachers future language-lab monitors - had to be well trained in the foreign language and given experience before taking up their key jobs as trainers of other teachers.

For every seminar, the teachers selected from each region were invited by the Ministry of Education to the Center in Santiago. They came by plane, train, or bus according to the distance from the capital city, and had their room and board at the Center premises without cost. 
Four stages were planned to achieve the correct orientation and training of future monitors through a great number of activities.

First stage: (April 1975) Introduction to the language lab and its methodology.

The specific objectives of this two week seminar were to:

- give the language lab monitors a complete and accurate knowledge of the use and operation of the language laboratory.

- determine the relationship between classroom work and language laboratory sessions.

- practice the language intensively. Teachers were supposed to be able to judge their own mistakes and other people's as well and to suggest exercises for remedial work.

Second stage: (September-October 1975) Intensive Training.

The objectives of this two week Seminar were to provide language lab monitors with:

- intensive practice in the use and operational system of the language laboratory.

- intensive practice in the language emphasizing oral production.

- organization of remedial work that would contribute to the development of total skill and fluency.

Third stage: (April to August 1976) CurrentTrends in Linguistics and Language Laboratory Methodology.

This was a correspondence - study course whose main objective was to give the future monitor an opportunity to become acquainted with recent trends in linguistics, educational theory and the role of the lab in foreign language acquisition. Participants had to read different books and articles and then prepare papers in three major areas: Linguistics; Phonology; Use and Misuse of the Language Lab.

The complete set of papers was mailed to every participant to be read and analyzed. A questionnaire asking for their opinion on several topics covered throughout the articles was sent at the end of this stage for candidates to complete and send back to our department.

Fourth stage: (September 1976) Terminal Training.

Yet another two week seminar was given to:

- provide each participant a final opportunity to improve his command of the language by means of an intensive program of language skills, emphasizing the phonological aspects of the language.

- assess the abilities acquired by the language lab monitors.

An additional seminar for the English team was yet given in January 1977. Thanks to a special contribution from the British Council, Miss 
Janet McAlpin, from the English Language Teaching Institute, London, gave a one week seminar on "The Exploitation of the Language Lab in In Service Training Programmes for Secondary School Teachers of English". This time the lab monitors had to pay their own transportation to Santiago; the Ministry provided only room and board.

It must be stressed now that after such a heavy program of activities we have 28 language laboratory monitors ready to start their job who have had in-service training.

\section{THE LABS AT WORK.}

The labs have been distributed in every region of the country. See figure below) So far 21 of them with their corresponding monitors in English and French are in use. An experimental stage took place from October to December 1976 in some of them. Teachers from the schools where the labs were installed as well as neighboring ones, were invited to participate. The main objectives were: a) to attract teachers to the lab and, b) to receive their opinions about some courses which could fit their needs. They had to fill in questionnaires specially prepared for this purpose.

The information received through these questionnaires has given us some light as to what are the teachers' weaknesses, preferences, likes and dislikes as far as language material is concerned.

We hope to have a National In-Service Training System at work in a few more months in every language laboratory installed in the country. We hope that with the work of our monitors plus the materials selected for the purpose, the quality of foreign language instruction in the classroom in Chile will improve. 
DISTRIBUTION OF LA.NGUAGE LABORATORIES FOR IN-SERVICE TRAINING

OF SECONDARY SCHOOL TEACHERS IN THE COUNTAY.

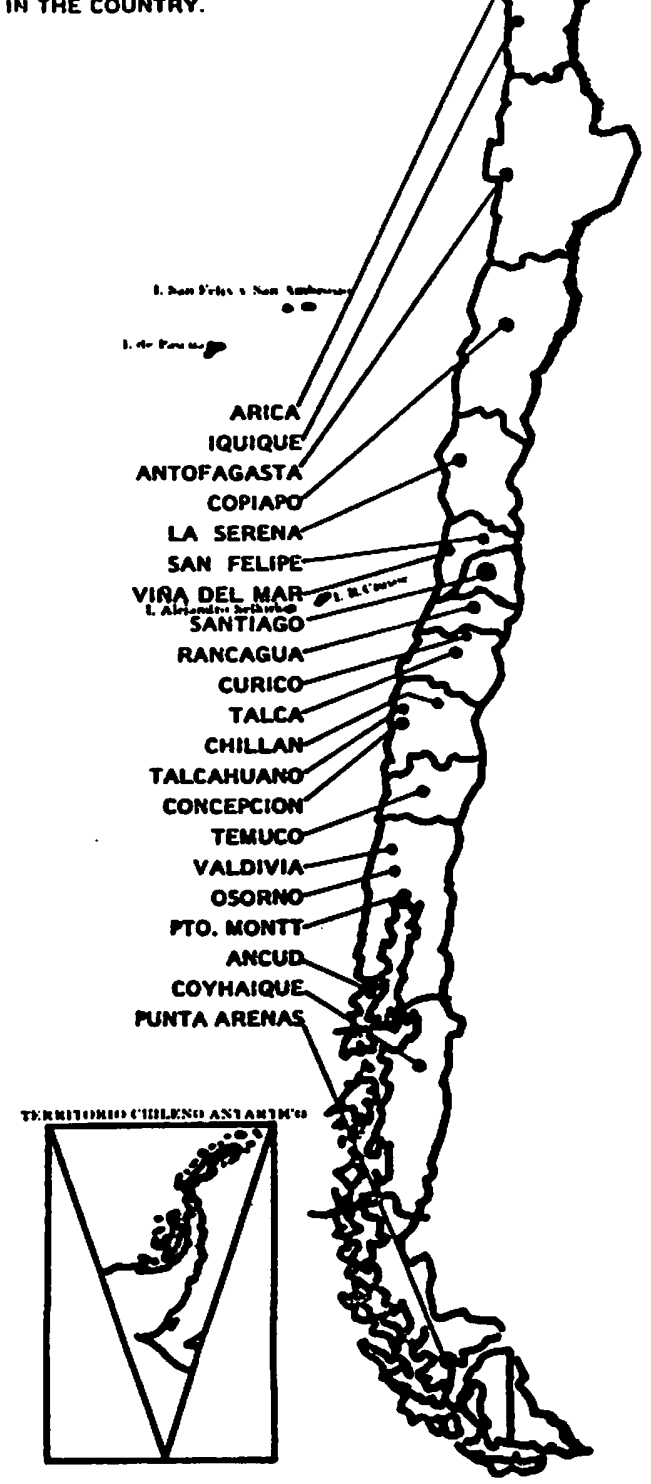

